\title{
Gestão Pública, Ética e Direitos Humanos
}

José Cláudio Rocha

Professor da Universidade do Estado da Bahia Doutor em Educação pela Universidade Federal da Bahia

Denise Abigail Britto Freitas Rocha

Professora da Universidade do Estado da Bahia Doutoranda em Educação pela Universidade Federal da Bahia

\section{Resumo}

A presente nota de pesquisa foi produzida na Universidade do Estado da Bahia (UNEB) pelo Grupo de Pesquisa Olhos D’água que investiga a (re)significação do espaço público a partir do enfoque da ética e dos direitos humanos procurando apontar soluções para os desafios brasileiros.

Palavras-chave: gestão pública; ética; direitos humanos.

\section{Resumen}

Lo presente artículo ha sido producido en la Universidad del Estado de Bahia por el grupo de investigación Ojos Delagua e indaga la resignificación del espacio público desde el foco de la ética e de los derechos humanos buscando apuntar soluciones para los desafíos brasileños.

Palabras-clave: gestión pública; ética; derechos humanos. 


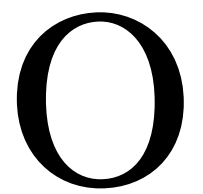

presente trabalho intitulado Gestão Pública, Ética e Direitos Humanos foi produzido na Universidade do Estado da Bahia (UNEB) pelo Grupo de Pesquisa Olhos D’água: Direitos Humanos, Ética, Capital Social, Desenvolvimento e Cidadania do Departamento de Ciências Humanas e Tecnologias (DCHT), Campus XIX, Camaçari, Bahia, Brasil.

Esta pesquisa foi apresentada no I Simpósio Nacional de Política, Ética e Educação: articulações no campo da Ética, promovido pela linha de pesquisa política, ética e educação - Grupo Paidéia - FE/UNICAMP e é fruto das observações realizadas pelo grupo de pesquisa sobre a inclusão do enfoque da ética e da Educação em Direitos Humanos (EDH) no âmbito da gestão pública, principalmente, através da formação de gestores públicos capazes de promover essa proposta não só no seu trabalho diário, como também nas estratégias de suas instituições.

Nossa reflexão parte da constatação de que no cenário político internacional existe uma urgência pelo reconhecimento da importância de um novo perfil profissional baseado na ética, no exercício democrático e solidário da cidadania, na promoção e defesa dos direitos humanos e no uso responsável do saber para a promoção de um desenvolvimento socialmente integrador e sustentável (ROCHA, 2009b).

Nesse sentido, a pesquisa busca contribuir com a construção de uma proposta de formação centrada na EDH como previsto no Plano Nacional de Educação em Direitos Humanos (PNEDH) e no Plano Nacional de Direitos Humanos (PNDH) em sua terceira versão. Concordamos com a idéia de que para termos gestores, professores e estudantes comprometidos com os direitos humanos é preciso fortalecer a educação em e para os direitos humanos no Brasil (ROCHA, 2009a).

Nosso objetivo é, portanto, a construção de um modelo de formação para o gestor público que além das habilidades técnicas consagradas, traga o desenvolvimento de habilidades éticas e sociais tendo como base a EDH. Essa medida visa no médio e longo prazo a construção de uma cultura de 
respeito e promoção aos direitos humanos, principal meta dos PNDG e PNEDH.

Essa reflexão nos levará necessariamente a uma reflexão sobre: em qual modelo civilizatório poderemos alicerçar nossas esperanças dos seres humanos viverem juntos e em paz consigo mesmo, com seus semelhantes e com o meio ambiente num mundo globalizado, multicultural e plural como o nosso; em quais princípios poderemos fundamentar o edifício de nossos códigos, convicções, condutas, princípios partilhados, certezas admitidas, projetos definidos e fidelidades herdadas; e em que futuro se possa crer e apostar.

Do ponto de vista metodológico, a pesquisa tem como referencial teórico a pesquisa qualitativa Straus e Corbin (2008), Denzin e Lincoln (2006) e FLICK (2009); a pesquisa-ação Thiolent (1992) e MORIN (2004). Outro referencial metodológico é a chamada Abordagem Baseada em Direito ou Right Based Approach (RBA $\left.{ }^{1}\right)$. A RBA tem como eixo os direitos humanos consagrados na Declaração Universal (DUDH) e em outros documentos internacionais de direitos humanos (ROCHA, 2011) entre outros.

O trabalho de campo é realizado com os gestores em seminários, debates e nos cursos de extensão e especialização lato sensu ${ }^{2}$ desenvolvidos pelo grupo sobre a temática. Nesses eventos, os professores e gestores são convidados a refletir sobre a pesquisa.

Como produto deste projeto, temos além dos livros, artigos e vídeos produzidos a proposta de construção de um Observatório sobre direitos

\footnotetext{
${ }^{1} \mathrm{O}$ escopo da RBA é que todo programa, projeto ou ação tenha como objetivo principal a realização de um direito ou de vários direitos humanos e o empoderamento das comunidades locais, principalmente, aquelas em situação de vulnerabilidade. Essa linha de trabalho na atualidade orienta a cooperação internacional em todos os setores como saúde, educação, governança, água, nutrição e saneamento básico, HIV/AIDS, emprego, relações de trabalho, relações sociais e desenvolvimento econômico.

${ }^{2}$ Curso de especialização na modalidade EAD aprovado pelo grupo de pesquisa em Edital da Universidade Aberta do Brasil (UAB), com recursos do MEC/SECAD e Secretaria de Direitos Humanos da Presidência da República (SDH/PR) para a formação de 400 especialistas em educação em direitos humanos na Bahia. Este curso tem previsão de início para o segundo semestre de 2011.
} 
humanos e EDH que se constituiu em um espaço virtual aberto à comunidade, acessível a todos que queiram publicar noticias, opiniões, artigos, criticas, comentários a respeito das atividades com direitos humanos no Brasil e no mundo.

Como resultados parciais da pesquisa desenvolvida temos, em primeiro lugar, a convicção de que não basta apenas a inclusão da ética e da EDH nos currículos dos gestores, muito menos a realização de mini cursos sobre o tema, mas reconhecer um novo emergência de um novo paradigma do saber, do ensino e da aprendizagem, que possa servir para pensar um desenvolvimento econômico, social e humano mais ético e solidário.

Por outro lado, chegamos à conclusão também de que é preciso conceber uma formação que não pode ser demasiadamente teórica ou idealista, mas uma formação que tenha no enfoque da ética e dos direitos humanos uma racionalidade técnica, pragmática, instrumental e estratégica, combatendo a dicotomia entre comportamentos éticos e uma prática administrativa eficiente e eficaz.

Cabe destacar ainda a importância de ampliar o acesso dos profissionais aos documentos internacionais de direitos humanos, bem como, reforçar a importância de utilização desses documentos como meios efetivos de construção das políticas públicas no Brasil. Os estudos realizados pelo nosso grupo de pesquisa ainda estão em caráter inicial e consideramos que após o curso de especialização lato sensu, teremos melhores condições de formular essa proposta, pois é fundamental a construção de uma proposta de formação fundamentada na ética, nos direitos humanos e no desenvolvimento econômico sustentável.

\section{Referências}

DENZIN, Normam e LINCOLN, Yvonna. O planejamento da pesquisa qualitativa: teorias e abordagens. Porto Alegre, Artmed, 2006. Série Métodos de pesquisa.

FLICK, Uwe. Desenho da pesquisa qualitativa. Porto Alegre, Artmed. 2009. 
Qualidade na pesquisa qualitativa. Porto Alegre, Artmed, 2009a.

MORIN, André. Pesquisa Ação Integral e Sistêmica. São Paulo, DP\&A, 2004.

ROCHA, José Cláudio. Abordagem Baseada em Direitos. Mimeo. Salvador, 2011.

EDUNEB, 2008.

A Reinvenção solidária e participativa da universidade. Salvador, Teoria do Estado Democrático. Salvador, EDUNEB, 2009.

2009a.

Guia de Educação em Direitos Humanos. Camaçari. UNEB.

. e ROCHA, Denise A. B. F. Metodologia de extensão em educação em direitos humanos. Camaçari, UNEB, 2009b.

STRAUSS, Anselm e CORBIN, Juliet. Pesquisa Qualitativa. Técnicas e procedimentos para o desenvolvimento de teoria fundamentada. $2^{\mathrm{a}}$ Edição. Porto Alegre, Artmed, 2008. Série Métodos de pesquisa.

THIOLENT, Michel. Metodologia da pesquisa-ação. São Paulo, Cortez, 1992. 